\title{
Pollen Toxicity from Seed-Treated Cotton on Bees and Pollen Collection Capacity
}

\author{
Ellen P. de Souza ${ }^{1}$, Paulo E. Degrande ${ }^{2}$, Rosalia Azambuja ${ }^{1}$, Ricardo O. dos Santos ${ }^{2}$, Valter V. Alves Junior ${ }^{1}$, \\ Rafael A. da Silva ${ }^{2} \&$ Mateus F. Leal ${ }^{2}$ \\ ${ }^{1}$ Faculdade de Ciências Biológicas e Ambientais, Universidade Federal da Grande Dourados, Dourados, MS, \\ Brazil \\ ${ }^{2}$ Faculdade de Ciências Agrárias, Universidade Federal da Grande Dourados, Dourados, MS, Brazil \\ Correspondence: Ellen P. de Souza, Faculdade de Ciências Biológicas e Ambientais, Universidade Federal da \\ Grande Dourados, Rodovia Dourados/Itahum, Km 12, Caixa Postal 533, CEP 79.804-970, Dourados, MS, Brazil. \\ Tel: 55-67-99698-2099. E-mail: ellen_psouza@hotmail.com
}

Received: August 1, 2017

doi:10.5539/jas.v9n11p154
Accepted: September 20, 2017

Online Published: October 15, 2017

\begin{abstract}
Apis mellifera bees that forage in agricultural fields may be exposed to pesticides through many routes. One of them is the collection of pollen contaminated with insecticides. In this study, we evaluate the mortality of adult honeybees exposed to pollen from cotton plants whose seeds were treated with insecticides thiamethoxam, clothianidin, imidacloprid and fipronil, and the pollen collection capacity of adult honeybees in cotton fields. Bee mortality based on linear regression analysis showed significant differences, but no differences were noted among treatments. According to the contrast analysis of the mean groups of insecticides against the mean of the control group, no significant differences were found, indicating a natural mortality for all treatments including the control. Quantitative analysis of the pollen revealed the presence of only cotton pollen grains on bees, indicating floral fidelity of Africanized honeybees. Pearson's correlation coefficient was positive, but statistically insignificant, for increase in pollen collection with time.
\end{abstract}

Keywords: Apis mellifera, treated seeds, neonicotinoids

\section{Introduction}

Cash crops, such as cotton, are susceptible to the pest attacks during growth, owing to the large areas they cover, among other factors. As a result, the use of pesticides during their cultivation is often necessary (Alves \& Serikawa, 2006; Andrei, 2013). However, some insects that are beneficial to the plants (e.g. pollinators) are exposed to harmful levels of chemicals in the environment that can reduce their activity in agricultural fields (Czepak et al., 2005; Santos \& Nascimento, 2011).

Concerns regarding the treatment of seeds with systemic insecticides for pest control during the early stages of development have been raised, owing to possible dispersion of high concentrations of neonicotinoids, such as thiamethoxam, clothianidin, imidacloprid, and the pyrazole fipronil in the environment, which could kill pollinators while foraging in agricultural fields (Krupe et al., 2012). Some studies have found residues of these pesticides in pollen, nectar, bees, and in the soil after planting, in addition to herbicides, fungicides, and acaricides (Mullin et al., 2010; Gill et al., 2012). It has been suggested that the quantity used is very small to have any effect on the mortality of pollinators, especially bees. However, others have pointed out a synergistic effect of these residues combined with viruses and mites; prolonged exposure to these compounds can weaken the bees, favoring the development of pathogens (Mullin et al., 2010; Gill et al., 2012).

Owing to the systemic action of insecticides, residues from seed treatments can be transported to various plant parts, and thus, accumulate in pollen grains. Imidacloprid residues have been found at concentrations of up to 13 ng in sunflower plants (Laurent \& Rathahao, 2003). Chauzat et al. (2006) identified 36 different types of residues in pollen loads in apiaries of France. Imidacloprid was the most frequently found compound (49.4\%), followed by 6-chloronicotinic acid (44.4\%) and fipronil (12.4\%) in the analyzed samples.

These residues may also affect the emergence of honeybee larvae and their lifespan, if their honeycombs are contaminated (Wu et al., 2011). When bees such as Apis mellifera Linnaeus, 1758, forage in agricultural fields, 
they may be exposed to these residues through various routes. One such example is collection of contaminated pollen, which is then transported by workers, and can subsequently affect the entire colony.

This study was aimed to evaluate the effects of pollen of cotton plants grown from treated seeds on the mortality of A. mellifera workers, and examine the capacity of bees to collect pollen in cotton fields, determining the collection rate and the period of highest cotton pollen collection.

\section{Material and Methods}

The study was conducted at the Experimental Farm and the Laboratory of Applied Entomology of the Federal University of Grande Dourados (Universidade Federal da Grande Dourados - UFGD), in Dourados, Mato Grosso do Sul, Brazil.

\subsection{Pollen Toxicity to A. mellifera Workers}

Containers were made using $2 \mathrm{~L}$ plastic bottles with several perforations for ventilation, a lateral entrance at the base of the bottle to allow bees to enter, and a lid to transfer the bees to testing cages. The neck of a spray bottle was attached to the lid of the $2 \mathrm{~L}$ bottle. This portion of the container was cut and a plastic barrier was placed to control the exit of bees.

Testing cages consisted of $700 \mathrm{~mL}$ plastic cups with lids and two side openings covered with mesh fabric. A hole was made in each lid to allow the transfer of bees from the collecting containers and closed with cotton moistened in a $20 \%$ honey solution with distilled water.

Bees were collected from a commercial beehive at $0700 \mathrm{~h}$, when the workers were leaving the colony to forage. Preliminary tests indicated that this period was the most appropriate to handle bees for the assays and to standardize the evaluation times.

Cotton plants of the variety NuOpal Bollgard were grown in a greenhouse. During flowering, pollen grains were collected daily from the plants with the aid of a brush. The collected pollen was stored at $-18{ }^{\circ} \mathrm{C}$ in plastic containers.

Plants were grown from untreated seeds (control) and seeds treated with chemical insecticides at the following concentrations, following the manufactures' instructions: clothianidin (Poncho ${ }^{\circledR} 600 \mathrm{SC}$ ) at $270 \mathrm{~g}$ a.i. $/ 100 \mathrm{~kg}$ of seeds, imidacloprid (Gaucho ${ }^{\circledR} 600 \mathrm{FS}$ ) at $270 \mathrm{~g}$ a.i. $/ 100 \mathrm{~kg}$ of seeds, thiamethoxam (Cruiser $\left.{ }^{\circledR} 350 \mathrm{FS}\right)$ at $210 \mathrm{~g}$ a.i./100 kg of seeds, fipronil (Standak ${ }^{\circledR} 250 \mathrm{SC}$ ) at $75 \mathrm{~g}$ a.i./100 $\mathrm{kg}$ of seeds.

Worker bees were collected directly from the beehive entrance and taken to the laboratory where they were transferred to testing cages. Each cage housed 10 workers that were fed $50 \mathrm{mg}$ of pollen mixed in $20 \mathrm{~mL}$ of honey and water in a cotton ball placed in the cage lid.

The first evaluation of pollen exposure to bees was carried out $1 \mathrm{~h}$ after all cages were set up. The interval between the evaluations gradually increased until $16 \mathrm{~h}$ of exposure $(1 \mathrm{~h}, 2 \mathrm{~h}, 4 \mathrm{~h}, 8 \mathrm{~h}$, and $16 \mathrm{~h})$. Bees were considered dead when they remained immobile after mechanical stimuli.

The experimental design consisted of randomized blocks of five treatments with 12 replicates each and 10 workers per replicate, totaling 120 bees per treatment.

\subsection{Evaluation of the Capacity to Collect Pollen for A. mellifera}

In a 1 hectare cotton field not treated with pesticides and with plants in full bloom, forage workers were collected using an insect net at intervals of 15 minutes from $0800 \mathrm{~h}$ to $1400 \mathrm{~h}$. The area was covered by walking slowly in a zig-zag pattern, as suggested by Cardoso et al. (2007). Sample collections were carried out on five consecutive days for seven evaluation periods, totaling 35 collections.

Bees were placed in a killing jar with ethyl acetate and then transferred to clean containers labeled with the collection day and time. Next, they were stored at $-18{ }^{\circ} \mathrm{C}$ for the qualitative and quantitative assessment of the pollen adhered to the following structures: femurs, tibias, and tarsomeres. The pair of hind legs was removed for the qualitative assessment regarding the origin of pollen, which was done under a light microscope using slides previously prepared with pollen from cotton flowers.

\subsection{Statistical Analysis}

The data for the capacity to collect pollen by worker bees against time were compared using Pearson's correlation coefficient. A random sampling was carried out to standardize the number of bees in each collection time. 
For analyzing the mortality of the bees fed with pollen from cotton plants grown from treated seeds, data were transformed by $\sqrt{\mathrm{x}+0.5}$, and analyzed using linear regression and Scheffe's contrast test.

\section{Results}

\subsection{Toxicity of Pollen to A. mellifera Workers}

The linear regression analysis revealed a significant relationship between bee mortality and exposure time in all treatments and the control group (Table 1). As the time of exposure to pollen from plants of the control group and those grown from treated seeds increased, mortality gradually increased (Figure 1).

According to the contrast analysis of the mean groups of insecticides against the mean of the control group, no significant differences were found, with a general mean mortality of 1.28 for workers among treatments and the control group.

Table 1. Analysis of variance of the linear regression of mortality of A. mellifera bees after feeding on pollen diluted in honey from cotton plants grown from treated seeds

\begin{tabular}{llllll}
\hline \multirow{2}{*}{ FV } & \multicolumn{5}{c}{ Mean square } \\
\cline { 2 - 6 } & tc & ti & th & tf & tt \\
\hline Treated & $24.816^{* *}$ & $31.600^{* *}$ & $40.233^{* *}$ & $25.9000^{* *}$ & $44.066^{* *}$ \\
Residue & 1.533 & 0.992 & 1.363 & 1.174 & 0.956 \\
\hdashline CV & 33.15 & 22.44 & 25.86 & 26.29 & 26.02 \\
\hline
\end{tabular}

Note. ${ }^{* *}$ Significant at $5 \%$. Data transformed by $\sqrt{\mathrm{x}+0.5} . \mathrm{CV}=$ coefficient of variation. tc $=$ treatment with clothianidin, $\mathrm{ti}=$ treatment with imidacloprid, $\mathrm{th}=$ treatment with thiamethoxam, $\mathrm{tf}=$ treatment with fipronil, and $\mathrm{tt}=$ control group (untreated). 

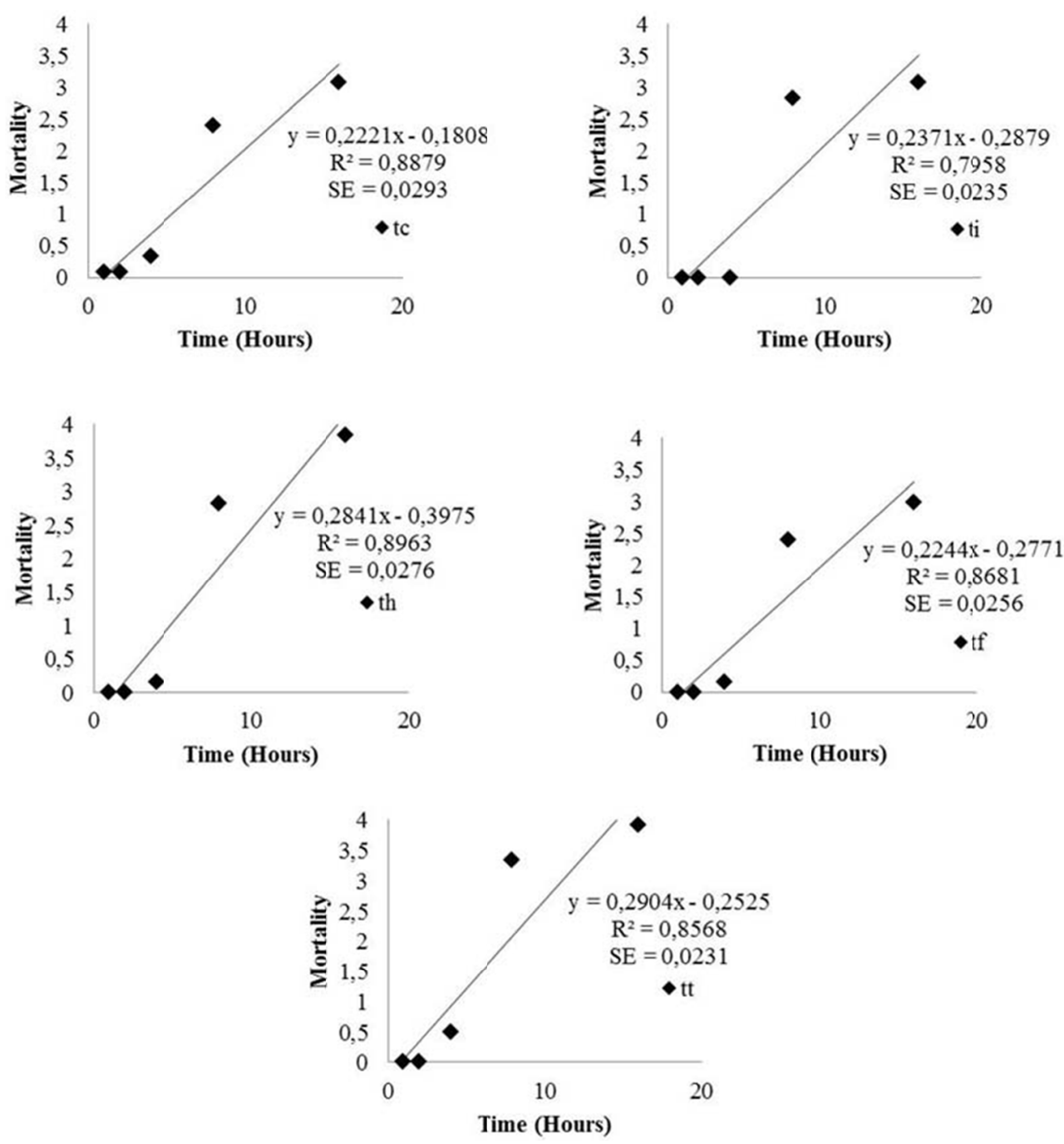

Figure 1. Mortality of bees fed with pollen of plants grown from seeds treated with clothianidin (tc), imidacloprid (ti), thiamethoxam (th), fipronil (tf), and the control group (tt). SE = standard error

\subsection{Pollen Collection Capacity of A. mellifera}

A total of 146 bees was collected, and 17,419 pollen grains were counted. A positive but statistically insignificant correlation was found with time $\left(r=0.3914, p=0.3852, S=74,88, S_{x}=28,30\right)$ (Figure 2).

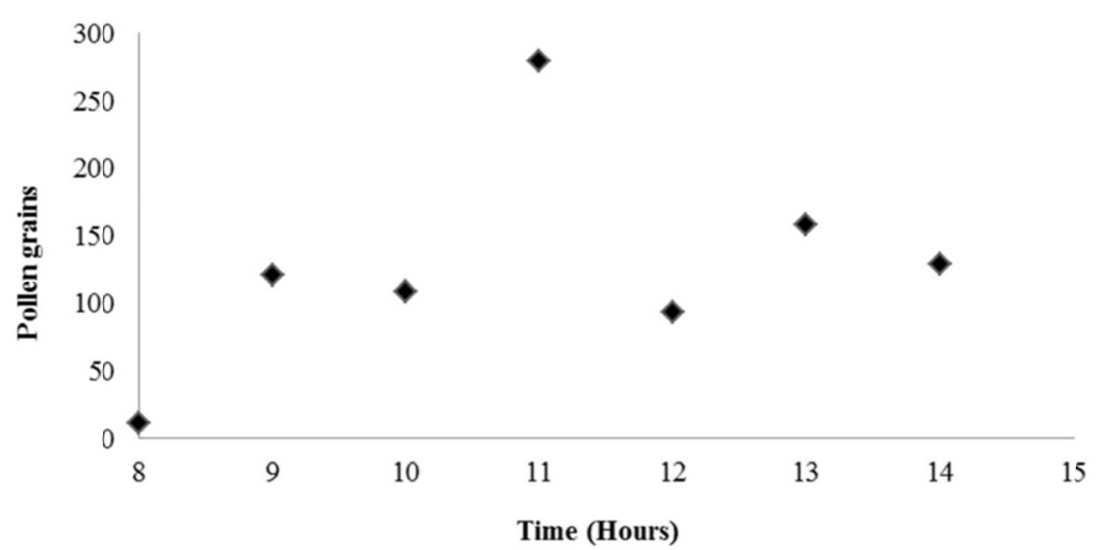

Figure 2. Pearson's correlation coefficient for pollen grains collected by A. mellifera workers with time in the cotton field 
Quantitative analysis of the pollen revealed the presence of only cotton pollen grains on bees, indicating floral fidelity of Africanized honeybees. Pollen grains of the cotton plants from which the bees foraged were observed on the entire body of bees. No pollen grains from other plant species were found on the examined workers.

Throughout the sampling periods, the number of collected pollen grains increased, peaking at $1100 \mathrm{~h}$ with a mean of 279.8 pollen grains, and then gradually decreased.

\section{Discussion}

\subsection{Toxicity of Pollen to A. mellifera Workers}

The mortality rates observed during the experiment where A. mellifera adults were exposed to pollen of plants grown from seeds treated with clothianidin, imidacloprid, thiamethoxam, and fipronil were similar to the natural rates. Therefore, no effects of pollen from plants grown from seeds treated with these insecticides were observed on the mortality of adult bees.

Studies conducted on imidacloprid have demonstrated that this insecticide is highly toxic to A. mellifera when ingested, with a $\mathrm{LD}_{50}$ of 3.7-40.9 ng per bee. However, in nectar and pollen, the residues of this insecticide have been found at very low levels $\left(0.0015 \mathrm{mg} \mathrm{kg}^{-1}\right)$ and represent a low risk to bees in the field (Schmuck et al., 2001). Faucon et al. (2005) did not find a significant difference in mortality rates when colonies were fed with imidacloprid at $0.5 \mathrm{mg}$ and $5 \mathrm{mg}$ diluted in $1 \mathrm{~L}$ of honey. Conversely, Lüken et al. (2014) conducted assays with A. mellifera larvae, where they fed them with the insecticides imidacloprid, clothianidin, thiacloprid, thiamethoxam, and fipronil, and reported significant increases in mortality for all the tested compounds. Tremolada et al. (2010) observed a higher mortality of bees from hives set up in fields planted with seeds treated with thiamethoxam and the fungicides fludioxonil and metalaxyl-M. These authors also observed a strong effect on the mortality of bees that were close to these areas, and reported that the number of foraging bees decreased as time progressed after planting.

Even if chemical residues are found in the pollen grains of plants, the concentrations found are lower than the $\mathrm{LD}_{50}$ of these insecticides (Schumuck et al., 2001, Bernal et al., 2010). Thus when adult bees collect and feed on pollen grains cotton plants that received seed treatment these do not pose a risk to adult of A. mellifera, as observed in this study.

However, the synergistic effects of these residues are still inconsistent and need further clarification on their effects on A. mellifera adults, since the variety of product residues found in both pollen and other products is high (Mullin et al., 2010).

Moreover the residues of insecticides may also affect the emergence of bees and their lifespan when combs are contaminated. Wu et al. (2011) found a wide variety of pesticides in beehives: carbamates, organophosphates, pyrethroids, and neonicotinoids (imidacloprid, thiamethoxam, clothianidin, dinotefuran, thiacloprid), among others. And observed that bees from brood combs not exposed to pesticides lived an average of four days longer than those from combs with high levels of these pesticides. However, they did not find significant differences in larval mortality between the control (26\%) and the contaminated cells $(33 \%)$.

However, when A. mellifera larvae are contaminated with different concentrations of insecticides, these can influence not only the mortality but also the delayed development of the larvae, suggesting that these low concentrations are more prejudicial to larvae than to A. mellifera bees adults since a sublethal effect may occur in larvae (Wu et al., 2011; Lüken et al., 2014).

Despite that studies on canola crops have examined the effects of clothianidin-treated seeds on A. mellifera. No differences were found regarding the exposure of hives during flowering, worker mortality, longevity, and brood development, despite the presence of clothianidin residues in honey, nectar, and pollen (Cutler \& Scott-Dupree, 2007).

Based on our findings, the pollen from cotton plants grown from seeds treated with thiamethoxam, clothianidin, imidacloprid, and fipronil did not affect the mortality of A. mellifera adult bees. Thus, under our experimental conditions, the cotton pollen seeded with seeds treated with these systemic insecticides not affect the survival of adult bees and would not pose risks to these insects during foraging, in the cotton crops that received this type of treatment and this practice is safe for bees when pollen is collected from plants grown from treated seeds. The insecticides used in the treatment of seeds are unlikely to pose risks to adult bees, and this practice is safe for bees when pollen is collected from plants grown from treated seeds. 
Nevertheless, if residues from treated seeds settle on nearby flowers during planting, and in higher quantities under field conditions, are worrisome. Therefore, further studies are needed to investigate this possibility in immature Africanized A. mellifera bees.

\subsection{Pollen Collection Capacity of A. mellifera}

Cardoso et al. (2007) reported that bees are usually more active and visit more flowers between $0900 \mathrm{~h}$ and 1300 h. In our study, the workers were foraging most actively in flowers of cotton plants at $1100 \mathrm{~h}$. It is known that $A$. mellifera workers frequently visit cotton fields and are their most abundant pollinators and the time of the day when bees are frequently observed is between $1000 \mathrm{~h}$ and $1300 \mathrm{~h}$ (Martins et al., 2008). During this period, the collection of resources might be higher due to the increase in individuals visiting plants, in agreement with our findings.

Some studies have demonstrated that $A$. mellifera bees are the most frequent visitors of cotton fields (36.7\%) and that they may collect pollen more actively than nectar (Malerbo-Souza \& Halak, 2011). Imperatriz-Fonseca et al. (1984), Ramalho et al. (1991), and Seeley (1995) suggested a high fidelity or "temporary specialization" between bees and the visited plants, with a strong tendency of not mixing pollen of different species.

However, although we found only cotton pollen grains on bees, they did not pack loads of pollen as usually found on their hind legs, thus, suggesting that the bees sampled were not effectively collecting pollen, but because of the large quantities of pollen attached to their bodies, they were acting as effective pollinators for cotton flowers.

Vaissière and Vinson (1994) conducted laboratory studies on pollen from cotton and other plants and reported a low efficiency of $A$. mellifera in collecting cotton pollen, as bees needed more time to pack the pollen and load size was reduced compared with the pollen from other plant species. This was associated with the length of spines on cotton pollen, and the structure of corbiculae was not suitable for the transport of cotton pollen due to its size, which interfered with the pollen aggregating process.

Although this morphological trait may hinder the transport of pollen by honeybees, the movement of cotton pollen to the hive occurs, even in small quantities, as they are attached to the body of bees. The exact behavior during pollen collection was not examined in this study, but during foraging, bees may be collecting nectar in cotton fields.

Other studies have shown that honeybees visit cotton fields for this type of activity, but the collection of nectar may be more frequent than that of pollen. However, as bees leave flowers, their bodies are covered with pollen (Martins et al., 2008), which may promote cross-pollination when they visit other flowers.

According to our findings, when A. mellifera bees visit cotton flowers, they become covered with pollen. However, bees do not pack the pollen in their hind legs as commonly observed in the field with other plants, indicating that they may prefer to collect nectar in cotton fields with this an amount of cotton pollen that is charged to a colony tends to be smaller.

Thus, the risk posed by pollen of cotton plants grown from treated seeds to honey bees is relatively low, since when they visit cotton fields, they prefer to collect nectar.

Our findings indicate that based on the behavior of bees and the quantities of pollen collected, further studies are needed to examine the toxicity of nectar from cotton plants grown from treated seeds to A. mellifera.

\section{References}

Alves, A. P., \& Serikawa, R. H. (2006). Controle químico de pragas do algodoeiro. Revista Brasileira de Oleaginosas e Fibrosas, 10(3), 1197-1209.

Andrei, E. (2013). Compêndio de defensivos agrícolas: Guia prático de produtos fitossanitários para uso agricola (9th ed., p. 1618). Organização Andrei, São Paulo.

Bernal, J., Garrido-Bailón, E., Del Nozal, M. J., González-Porto, A. V., Martín-Hernández, R., Diego, J. C., ... Higes, M. (2010) Overview of Pesticide Residues in Stored Pollen and Their Potential Effect on Bee Colony (Apis mellifera) Losses in Spain. Journal of Economic Entomology, 103(6), 1964-1971. https://doi.org/10.1603/EC10235

Cardoso, C. F., Silveira, F. A., Oliveira, G. M., Cavéchia, L. A., Almeida, J. P. S., Nakasu, E. Y. T., ... Pires, C. S. S. (2007). Principais polinizadores de Gossypium hirsutum latifolium cv. Delta Opal (Malvaceae), em uma localidade do Distrito Federal, Brasil (p. 43). Boletim de Pesquisa e Desenvolvimento/Embrapa Recursos Genéticos e Biotecnologia, Brasília. 
Chauzat, M. P., Faucon, J. P., Martel, A. C., Lachaize, J., Cougoule, N., \& Aubert, M. (2006). A survey of pesticide residues in pollen loads collected by honey bees in France. Journal of Economic Entomology, 99(2), 253-262. https://doi.org/10.1093/jee/99.2.253

Cutler, G. C., \& Scott-Dupree, C. D. (2007). Exposure to Clothianidin Seed-Treated Canola Has No Long-Term Impact on Honey Bees. Journal of Economic Entomology, 100(3), 765-772. https://doi.org/10.1093/jee/ 100.3.765

Czepak, C., Fernandes, P. M., Albernaz, K. C., Rodrigues, O. D., Silva, L. M., Silva, E. A., ... Borges, J. D. (2005). Seletividade de inseticidas ao complexo de inimigos naturais na cultura do algodão (Gossypium hirsutum L.). Pesquisa Agropecuária Tropical, 35(2), 123-127.

Faucon, J. P., Aurières, C., Drajnudel, P., Mathieu, L., Ribière, M., Martel, A. C., ... Aubert, M. F. (2005). Experimental study on the toxicity of imidacloprid given in syrup to honey bee (Apis mellifera) colonies. Pest Management Science, 61(2), 111-125. https://doi.org/10.1002/ps.957

Gill, R. J., Ramos-Rodrigues, O., \& Raine, N. E. (2012). Combined pesticide exposure severely affects individual- and colony-level traits in bees. Nature, 491(7422), 105-108. https://doi.org/10.1038/nature11585

Imperatriz-Fonseca, V. L., Kleinert-Giovannini, A., Cortopassi-Laurino, M., \& Ramalho, M. (1984). Hábitos de coleta de Tetragonisca angustula angustula Latreille (Hymenoptera: Apidae, Meliponinae). Boletim de Zoologia, 8, 115-131. https://doi.org/10.11606/issn.2526-3358.bolzoo.1984.122174

Krupe, C. H., Hunt, G. J., Eitzer, B. D., Andino, G., \& Given, K. (2012). Multiple routes of pesticide exposure for honey bees living near agricultural fields. Plos One, 7(1), 1-8.

Laurent, F. M., \& Rathahao, E. (2003). Distribution of [(14)C] imidacloprid in sunflowers (Helianthus annuus L.) following seed treatment. Jounal of Agricultural and Food Chemistry, 51(27), 8005-8010. https://doi.org/ $10.1021 / \mathrm{jf0} 34310 \mathrm{n}$

Lüken, D. J., Janke, M., Lienau, F. W., Gerdel, K., von der Ohe, W., \& Forster, R. (2014). Optimisation of an in vitro larvae test to test the effects of plant protection products on honeybee brood (Apis mellifera L.). Journal für Verbraucherschutz und Lebensmittelsicherheit, 9, 157-166. https://doi.org/10.1007/ s00003-014-0865-0

Malerbo-Souza, D. T., \& Halak, A. L. (2011). Frequência e comportamento de abelhas e outros insetos nas flores do algodoeiro (Gossypium hirsutum L.). Zootecnia Tropica, 29(4), 475-484.

Martins, C. F., Zanella, F. C. V., Melo, R. R., \& Camarotti, M. F. (2008). Visitantes florais e polinização do algodoeiro (Gossypium hirsutum L.) semi-árido nordestino. Revista Brasileira de Oleagionas Fibrosas, 12(3), 107-117.

Mullin, C. A., Frazier, M., Frazier, J., Ashcraft, S., Simonds, R., vanEngelsdorp, D., \& Pettis, J. S. (2010). High Levels of Miticides and Agrochemicals in North American Apiaries: Implications for Honey Bee Health. PLoS ONE, 5(3), e9754. https://doi.org/10.1371/journal.pone.0009754

Ramalho, M., Guibu, L. S., Giannini, T. C., \& Kleinert-Giovannini, A. (1991). Ecologia nutricional de abelhas sociais. In A. R. Panizzi \& J. R. P. Parra (Eds.), Ecologia nutricional de insetos e suas implicações no manejo de pragas (pp. 225-252). São Paulo, Ed. Manole Ltda.

Santos, A. B., \& Nascimento, F. S. (2011). Diversidade de visitantes florais e potencias polinizadores de Lycopersicon esculenteum (Linnaeus) (Solanales: Solanaceae) em cultivos orgânicos e convencionais. Neotropical Biology and Conservation, 6(3), 162-169.

Schmuck, R., Schöning, R., Stork, A., \& Schramel, O. (2001). Risk posed to honeybees (Apis mellifera L, Hymenoptera) by an imidacloprid seed dressing of sunflowers. Pest Management Science, 57(3), 225-238. https://doi.org/10.1002/ps.270

Seeley, T. D. (1995). The wisdom of the hive-The social physiology of honey bee colonies (p. 295). Londres, Harvard University Press.

Tremolada, P., Mazzoleni, M., Saliu, F., Colombo, M., \& Vighi, M. (2010). Field Trial for Evaluating the Effects on Honeybees of Corn Sown Using Cruiser and Celest xl Treated Seeds. Bulletin of Environmental Contamination and Toxicology, 85, 229-234. https://doi.org/10.1007/s00128-010-0066-1

Vaissière, B. E., \& Vinson, S. B. (1994). Pollen morphology and its effect on pollen collection by honey bees, Apis mellifera L. (Hymenoptera: Apidae), with special Reference to upland cotton, Gossypium hirsutum L. (Malvaceae). Grana, 33(3), 128-138. https://doi.org/10.1080/00173139409428989 
Wu, J. Y., Anelli, C. M., \& Sheppard, W. S. (2011). Sub-Lethal Effects of Pesticide Residues in Brood Comb on Worker Honey Bee (Apis mellifera) Development and Longevity. PLoS ONE, 6(2), e14720. https://doi.org/ 10.1371/journal.pone.0014720

\section{Copyrights}

Copyright for this article is retained by the author(s), with first publication rights granted to the journal.

This is an open-access article distributed under the terms and conditions of the Creative Commons Attribution license (http://creativecommons.org/licenses/by/4.0/). 